\title{
Modeling of the Water Table Level Response Due to Extraordinary Precipitation Events: The Case of the Guadalupe Valley Aquifer
}

\author{
Javier González Ramírez, Rogelio Vázquez González \\ Earth Sciences Division, Center for Scientific Research and Higher Education at Ensenada, Ensenada, Mexico \\ Email: avgonza@cicese.edu.mx, rvazquez@cicese.mx
}

Received May 13, 2013; revised June 23, 2013; accepted July 19, 2013

Copyright (C) 2013 Javier González Ramírez, Rogelio Vázquez González. This is an open access article distributed under the Creative Commons Attribution License, which permits unrestricted use, distribution, and reproduction in any medium, provided the original work is properly cited.

\begin{abstract}
A two-dimensional algorithm for underground water flow simulation was modified and adapted to the geohydrologic conditions of the Guadalupe valley located in the state of Baja California in northern México. In order to solve the numerical model using the balance equation, the central finite differences with spatial and temporal constant increments method were used. Such model considers a heterogeneous and transient unconfined aquifer. Modeling and calibration processes are presented using the data of water table levels provided by the water level data loggers installed in a monitoring network and precipitation data from climatic stations of both seasons: 2009-2010 and 2010-2011. It was possible to locate, correlate and model specific rainfall-recharge events with the aim of obtaining an estimation of how these events are directly reflected on the water table level of the aquifer and how it reacts against simulated extraordinary events.
\end{abstract}

Keywords: Geohydrologic Model; Precipitation; Recharge; Finite Differences Method

\section{Introduction}

In the northern state of Baja California, the water supply and water quality for human, agriculture and industry consumption is a crucial issue for the development of the region. Guadalupe valley in the Ensenada municipality is the country's most important area for wine making and its water supply comes from an unconfined aquifer that recharges from the Sierra Juárez runoff. Because of this industry and the fact that the aquifer provides water for the consumption of the city of Ensenada, it has been documented an overexploitation of the resource.

The studied aquifer recharges thru: superficial and underground flows from the upper Guadalupe basin via the Guadalupe river area, underground flow due to runoff in the surrounding mountains and vertical recharge constituted by percolation of the direct precipitation; for the study of such processes a numerical solution was proposed.

Numerical solutions using finite difference methods have been used by modelers for decades, a modified and adapted two dimensional groundwater flow model based in the algorithm generated by Vázquez et al. [1] was used to run all the simulations. This paper presents the results of the simulated response of the water table in the Guadalupe valley's aquifer due specific extraordinary precipitation events in the Guadalupe basin and compares the results with the data provided by the level loggers installed in monitoring network.

There are several studies concerning the operation conditions and the geohydrological characteristics of the Guadalupe valley's aquifer, within the institutions that carried out such studies we can name the SARH (Secretaría de Agricultura y Recursos Hidráulicos), CNA (Comisión Nacional del Agua), CICESE (Centro de Investigación Científica y de Educación Superior de Ensenada) and COTAS (Comité Técnico de Aguas Subterráneas). Campos [2] in his doctoral thesis performed a groundwater flow simulation of the aquifer considering monthly time intervals starting on February 1984 and simulated 21 years corresponding to the calibration period, then, he compared the resulting data with historical water table levels for the same time period. Eventually he proposed different extraction scenarios and simulated another 20 years corresponding to the forecast period in order to find sustainable extraction rates for human and agriculture water 
consumption.

\section{Study Area}

The Guadalupe valley (Figure 1) with an estimated surface area of $\sim 103 \mathrm{~km}^{2}$ is located in the Guadalupe basin in the northwest region of Baja California state, Mexico; according to the modified Köpen climate classification [3] the study area has a moderated semi arid climate with a mean annual temperature of $18^{\circ} \mathrm{C}$ and an average annual rainfall of $300 \mathrm{~mm}$ which mainly occurs from late November to early February. The primary land use is irrigated and rain-fed agriculture, vines and olive trees are the main cultivated crops.

From a geological point of view, diverse fault processes created two major basins noticeably aligned in a northeast southwest direction, these basins were eventually filled with unconsolidated materials product of transport and depositional processes finally forming the valley area. The surrounding area as well as the confining basement of the aquifer is mainly integrated by intrusive igneous rocks $[4,5]$.

The unconfined aquifer in the valley extends over 60 $\mathrm{km}^{2}$ and the confining bedrock depth, reported by Nájera [6] and Vázquez et al. [7] using geophysical methods, varies from $\sim 70 \mathrm{~m}$ in the southwest basin to $\sim 290 \mathrm{~m}$ in the northeast basin. There are approximately 1374 extraction sites (wells, dug wells and springs), which 754 are functional and only 186 are major wells extracting an estimated $19 \mathrm{Mm}^{3}$ per year [8] to satisfy the agricultural and human consumption needs from the valley and the city of Ensenada.

\section{The Data Processing}

\subsection{Water Table Data}

The water table data in the present work was provided entirely by the monitoring network put into operation in 2007 [7] and currently operated by COTAS, such network is made up of 16 monitoring wells equipped with level loggers distributed along the valley and 1 barometer installed in the middlemost well. Despite there are records from 2007, due to lack of continuity in the level data, it was possible to work only with information for the period 2010-2012.

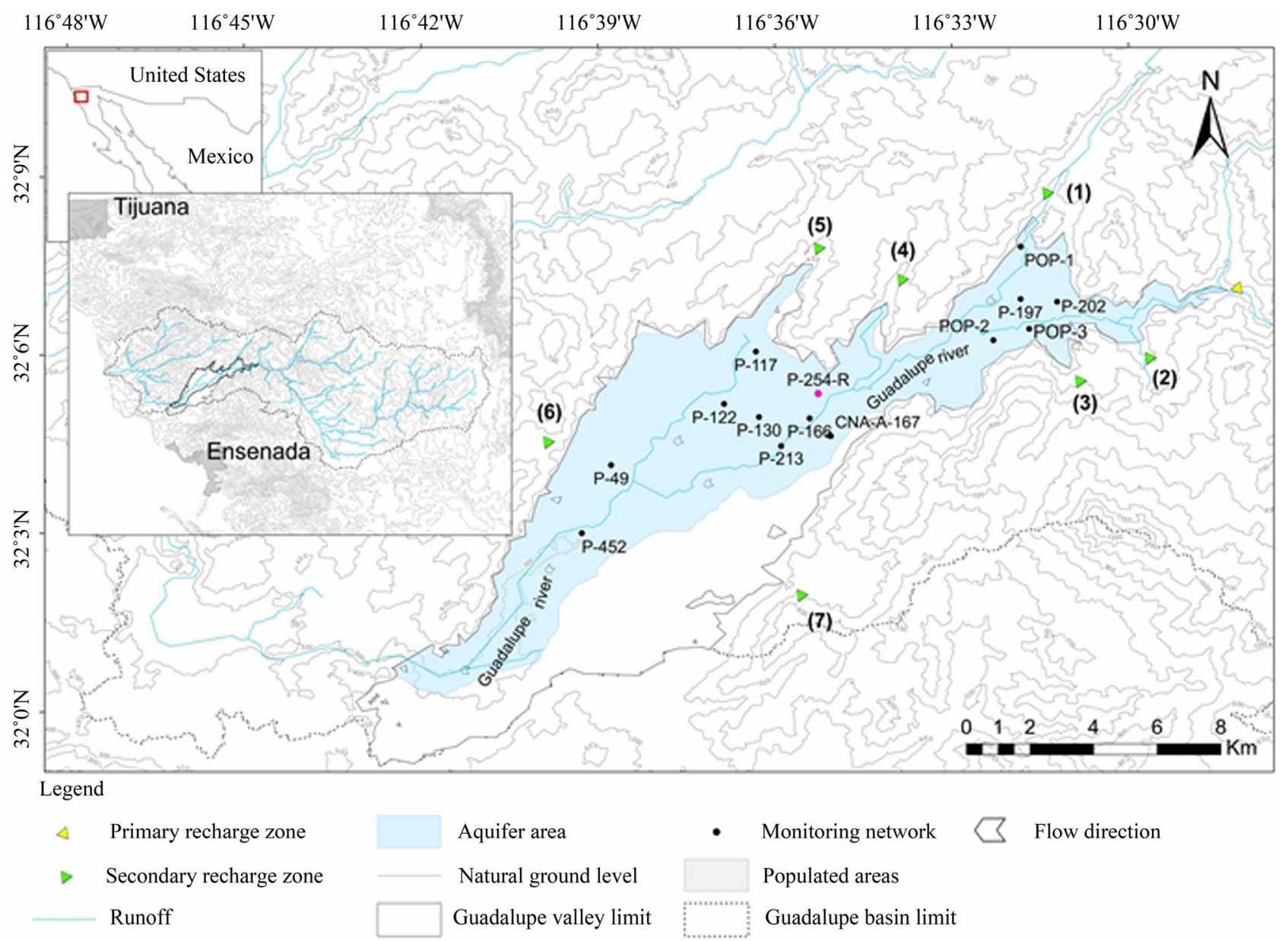

Figure 1. General description of the study area. 
It is because the level loggers measure absolute pressure a barometric correction has to be made, such correction was performed directly by subtracting the barometric register, provided by the barometer installed in the P-254-R well, from the raw water table register provided by the loggers (Figure 2).

\subsection{Rainfall Data}

In order to locate and correlate specific rainfall events with the increase in the water table level the precipitation data from 2 meteorological stations were used: Valle de Guadalupe and El Mogor stations (both located in the valley area). All the data provided had a 10-minute in- terval, however, for this work they were grouped into 1 day period, which is the time interval used in all the simulations. It is important to mention that in order to study the runoff recharge mechanism the precipitation data were considered as hydrologic seasons e.g. June 1, 2010-May 31, 2011. Using the existing data was possible to locate extraordinary rainfall events considering as extraordinary events those in which the precipitation reaches values higher than $22 \mathrm{~mm}$ in one day (Figure 3), and then correlate such events with water table level increments recorded in the loggers of the monitoring network to finally observe the lag between rainfall and level increase.

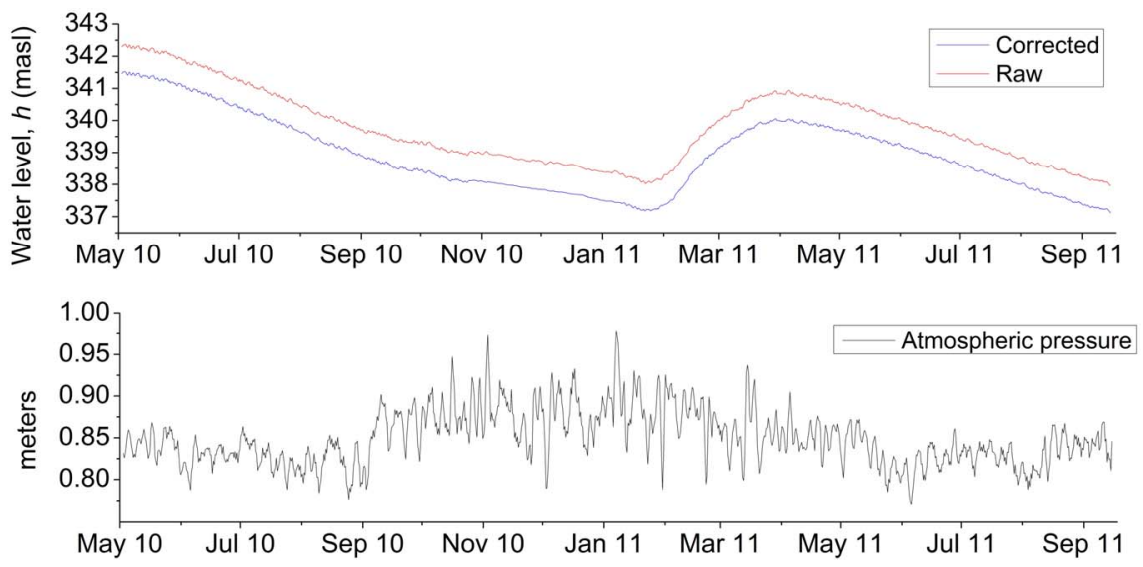

Figure 2. Above, raw and corrected water table level of the $\mathrm{P}-202$ well. Below, atmospheric pressure record provided by the instrument installed in the $\mathrm{P}-254 \mathrm{R}$ well used in the barometric correction process.
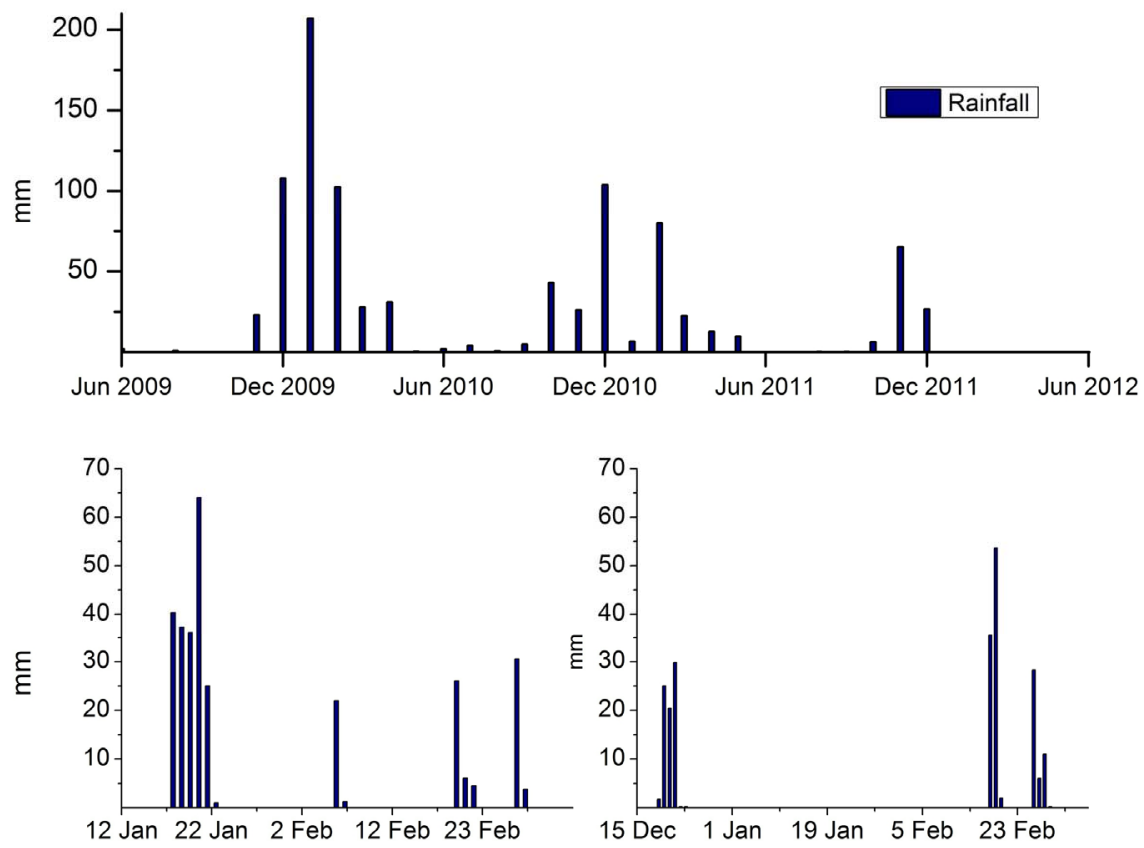

Figure 3. Above, monthly average precipitation of the studied seasons. Below left, daily average precipitation emphasizing the extraordinary precipitation events in the 2009-2010 season. Below right, daily average precipitation and the extraordinary events for the 2010-2011 season. 


\section{Modeling}

\subsection{Model}

All the model simulations were performed in a model built using an existing algorithm [1] based in the bidimensional form of the Boussinesq equation:

$$
\frac{\partial}{\partial x}\left(K_{x} b \frac{\partial h}{\partial x}\right)+\frac{\partial}{\partial y}\left(K_{y} b \frac{\partial h}{\partial y}\right)=S \frac{\partial h}{\partial t}-R
$$

where:

$$
b=h-d
$$

$K$ is the hydraulic conductivity, $h$ is the water table level, $d$ is the bedrock elevation, $S$ is the specific storage, $R$ refers to sources or sources, $x$ and $y$ are the spatial variables and $t$ is the temporal variable. Such model was programmed in Matlab R2008b and it solves a case for an unconfined and heterogeneous aquifer in both stationary and transitory state using the central finite differences for the spatial intervals and forward finite differences for time intervals in order to solve the balance equation to compute Hc (see below).

where:

$$
S E_{C}=\frac{S_{C} \cdot \Delta d^{2}}{\Delta t}
$$

$H$ refers to the water table level, $T$ is the product of the of a equivalent hydraulic conductivity in two adjacent cells by the saturated thickness, $S$ is the specific storage coefficient, $\Delta d$ and $\Delta t$ are the corresponding spatial and temporal intervals. All the model input parameters, recharges and extractions for the studied aquifer were introduced in $170 \times 120$ matrices of which 5604 are active cells of $150 \times 150 \mathrm{~m}$ each.

\subsection{Initial Geohydrological Parameters}

The input geohydrological parameters entered into the model were: initial water table data obtained from the level loggers installed in the monitoring network, DEMs (Digital Elevation Models) distributed by the USGS [9] for topography data, confining bedrock depths reported by Nájera [6] and Vázquez et al. [7] using geophysical methods and finally both hydraulic conductivities and storage coefficients (Table 1) provided by CNA [8].

\subsection{System Inputs}

Horizontal recharge product of a precipitation volume over the $\sim 1841.45 \mathrm{~km}^{2}$ corresponding to the runoff contribution area, it takes place throughout the year and is defined by proposed percentages that changed during the calibration process; this recharge enters the system thru specified recharge areas (Figure 1).

Vertical recharge as result of the direct precipitation over the valley area $\left(\sim 103.55 \mathrm{~km}^{2}\right)$ and subsequent percolation, unlike horizontal recharge vertical recharge occurs only in the precipitation season and not along the year.

In addition to the aforementioned regular recharges, the model considers an extraordinary recharge defined by the runoff volume thru the Guadalupe river area produced by sudden precipitation events ( $>22 \mathrm{~mm}$ per day).

All recharge volumes were calculated with the rainfall data provided by the two meteorological stations mentioned before: Valle de Guadalupe and El Mogor. Based on previous studies [10] and information of the area [11], all the direct contribution percentages to the aquifer started at $10 \%$ and were changing in the calibration process.

\subsection{System Extractions}

There are two different types of extraction occurring in the aquifer: pumping and evapotranspiration, the main pumping extraction for agricultural, industrial and domestic use occurs thru 186 relevant extraction sites (deep wells, shown in Figure 4) and an approximate of 19 $\mathrm{Mm}^{3}$ are extracted [8] of which $9.5 \mathrm{Mm}^{3}$ are for the consumption of the city of Ensenada. CNA [8] calculated an annual average potential evapotranspiration of $240 \mathrm{~mm}$ using the data provided by the climatological stations Olivares Mexicanos y Agua Caliente, considering the proposed value and applying it to the cell area that the model uses $(150 \mathrm{~m} \times 150 \mathrm{~m})$, we obtained an estimate of the annual potential EVT (Table 2) in the cells in which the EVT model tool were activated.

$$
\mathrm{EVT}=\left(22,500 \mathrm{~m}^{2}\right)(0.240 \mathrm{~m})=5400 \frac{\mathrm{m}^{3}}{\mathrm{yr}} \text { per cell }
$$

It is important to mentioning that the EVT tool was activated only on those cells in which the water table level is above of a specified extinction depth (Figure 4).

\section{Results}

\subsection{Data Analysis}

It was possible to identify and correlate extraordinary precipitation and water table level increments for both seasons 2009-2010 and 2010-2011 in the level records corresponding to the CNA-A-167, P-213, POP-3, POP-2, P-202 and P-452 wells. Likewise it was possible to

$$
H_{C}^{k+1}=\frac{T_{S C} H_{S}^{k+1}+T_{N C} H_{N}^{k+1}+T_{E C} H_{E}^{k+1}+T_{O C} H_{O}^{k+1}+R_{C}^{k+1}+S E_{C} H_{C}^{k}}{T_{S C}+T_{N C}+T_{E C}+T_{O C}+S E_{C}}
$$


Table 1. Coefficients and percentages that best adjusted the simulated response with the observed data.

\begin{tabular}{|c|c|c|}
\hline Hydraulic conductivity ranges (m/day) & \multicolumn{2}{|c|}{$2-8$} \\
\hline Specific storage & \multicolumn{2}{|c|}{$0.10-0.28$} \\
\hline \multicolumn{3}{|l|}{ Contribution rates } \\
\hline Total runoff contribution to the aquifer drained from Guadalupe basin (initial 10\%) & \multicolumn{2}{|c|}{$3 \%$} \\
\hline \multirow{12}{*}{ Monthly contribution percentage of total recharge volume } & January & $5 \%$ \\
\hline & February & $20 \%$ \\
\hline & March & $13 \%$ \\
\hline & April & $14 \%$ \\
\hline & May & $12 \%$ \\
\hline & June & $11 \%$ \\
\hline & July & $8 \%$ \\
\hline & August & $7 \%$ \\
\hline & September & $4 \%$ \\
\hline & October & $2 \%$ \\
\hline & November & $1 \%$ \\
\hline & December & $3 \%$ \\
\hline Percentage of total volume recharging thru primary zone & \multicolumn{2}{|c|}{$50 \%$} \\
\hline & \multicolumn{2}{|c|}{$50 \%$} \\
\hline & \multicolumn{2}{|c|}{ Percentage of volume recharging per zone } \\
\hline Percentage of total volume recharging thru secondary zones & \multicolumn{2}{|c|}{$\begin{array}{c}\text { Zone 1: } 25 \% \\
\text { Zone } 2: 15 \% \\
\text { Zone 3: } 25 \% \\
\text { Zone } 4: 3 \% \\
\text { Zone } 5: 10 \% \\
\text { Zone } 6: 2 \% \\
\text { Zone } 7: 20 \%\end{array}$} \\
\hline
\end{tabular}

Table 2. Monthly evapotranspiration extractions values.

\begin{tabular}{|c|c|c|c|c|}
\hline Month & Solar radiation for $32^{\circ} \mathrm{N}$ latitude (watts $/ \mathrm{m}^{2}$ ) & $\mathrm{EVT} \%$ & Annual EVT volume $\left(\mathrm{m}^{3} / \mathrm{cell}\right)$ & Monthly EVT volume $\left(\mathrm{m}^{3} / \mathrm{cell}\right)$ \\
\hline January & 90.84 & $4.44 \%$ & \multirow{12}{*}{5400} & 239.64 \\
\hline February & 127.28 & $6.22 \%$ & & 335.77 \\
\hline March & 184.21 & $9.00 \%$ & & 485.95 \\
\hline April & 221.53 & $10.82 \%$ & & 584.38 \\
\hline May & 220.71 & $10.78 \%$ & & 582.22 \\
\hline June & 223.71 & $10.93 \%$ & & 590.14 \\
\hline July & 234.35 & $11.45 \%$ & & 618.21 \\
\hline August & 221.24 & $10.81 \%$ & & 583.61 \\
\hline September & 191.79 & $9.37 \%$ & & 505.92 \\
\hline October & 145.78 & $7.12 \%$ & & 384.56 \\
\hline November & 103.35 & $5.05 \%$ & & 272.62 \\
\hline December & 82.26 & $4.02 \%$ & & 216.99 \\
\hline
\end{tabular}

observe and estimate the lag between such precipitation events and the associated water table level increments.

\subsubsection{Season 2009-2010}

Four relevant precipitation events were located in this season (Figure 3): January 18-22, 2010 with $203 \mathrm{~mm}$, being January 21 the most relevant with $64.07 \mathrm{~mm}$; Feb- ruary 6, 2010 with $22.03 \mathrm{~mm}$, February 20 with 26.09 $\mathrm{mm}$ and February 27 with $30.59 \mathrm{~mm}$.

\subsubsection{Season 2010-2011}

It was possible to locate three mayor events in this season (Figure 3); the first took place on December 20-22 with $\sim 75.35 \mathrm{~mm}$, the second one on February 18-19, 


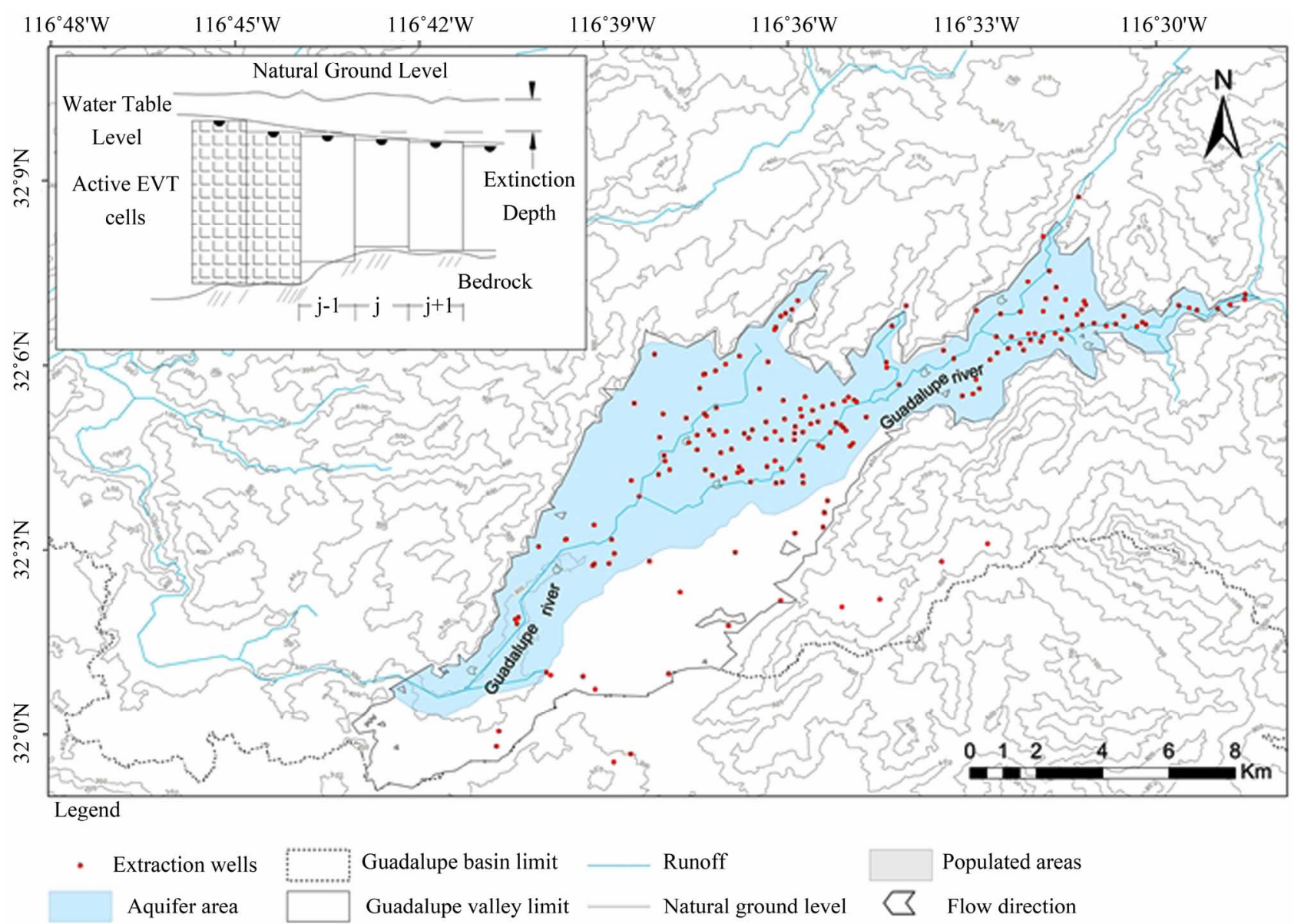

Figure 4. Description of the EVT tool activation and extraction sites in the Guadalupe valley area and. Only wells located within the area of the aquifer were used in the simulations.

2011 with 35.49 and $53.74 \mathrm{~mm}$ respectively and the third event on February 26, 2011 with $28.31 \mathrm{~mm}$.

\subsection{Calibration Process}

Once performed the data analysis, all the information was entered in the model to began with the calibration process; such process was based in the following assumptions result of the previous analysis: 1) two response processes could be observed in the Guadalupe valley's aquifer: slow response (due to horizontal recharge and quick response (due to extraordinary recharge and vertical recharge); 2) the slow response occurs throughout the year and is defined by direct monthly contribution percentages to the aquifer; 3 ) the quick response is governed by the extraordinary precipitation events intensity in the Guadalupe basin and it occurs mainly thru the Guadalupe river (Figure 5).

\subsection{Simulation}

A 720 stress period using 1 day intervals simulation starting on January 1st 2010 and ending on December 31st, 2011 was performed; it was possible to simulate sudden recharge in order to observe the water table level quick response in the aquifer. All the results are presented in Figures 6 and 7 in which one can observe the measured water table level data, the simulated water table level data and the extraordinary precipitation events related to the peaks.

\section{Discussion}

The water table level data provided by the monitoring network operated by COTAS had some limitations; de spite it is a large compendium of data, the mishandling of the data loggers resulted in information gaps in the first years of monitoring (2007-2009).

Using the available data it was possible to identify, correlate and model significant water table increases with precipitation events in the period 2009-2011. According to this data and the model results, the water table level response against extraordinary precipitation events was evident in the Guadalupe river and nearby areas (wells P-202, POP-3, POP-2,CNA-A-167, P-213 and P-452, shown in Figure 6). One can observe that the most 


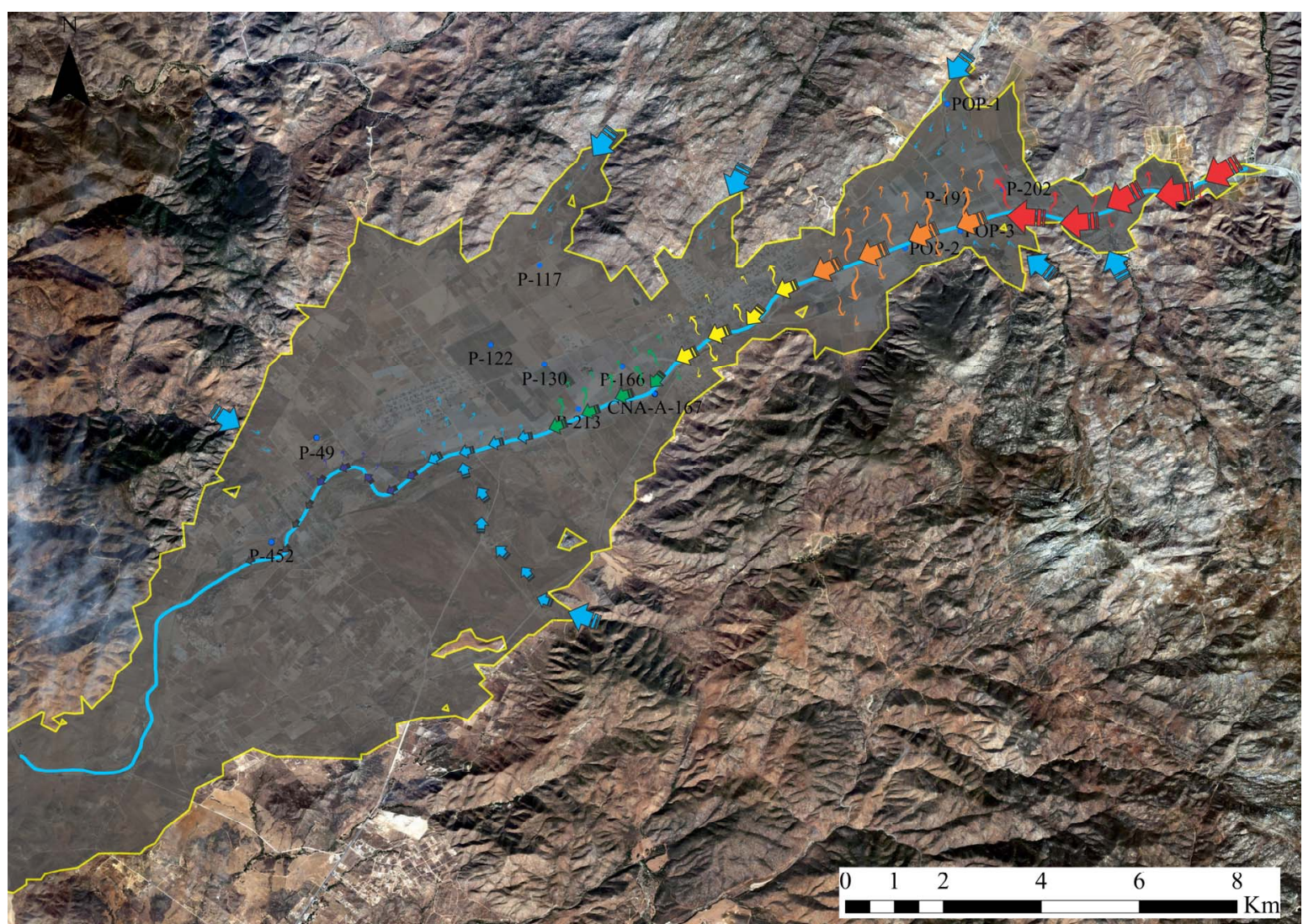

Figure 5. Assumed recharge mechanism to the aquifer according to the analyzed data.
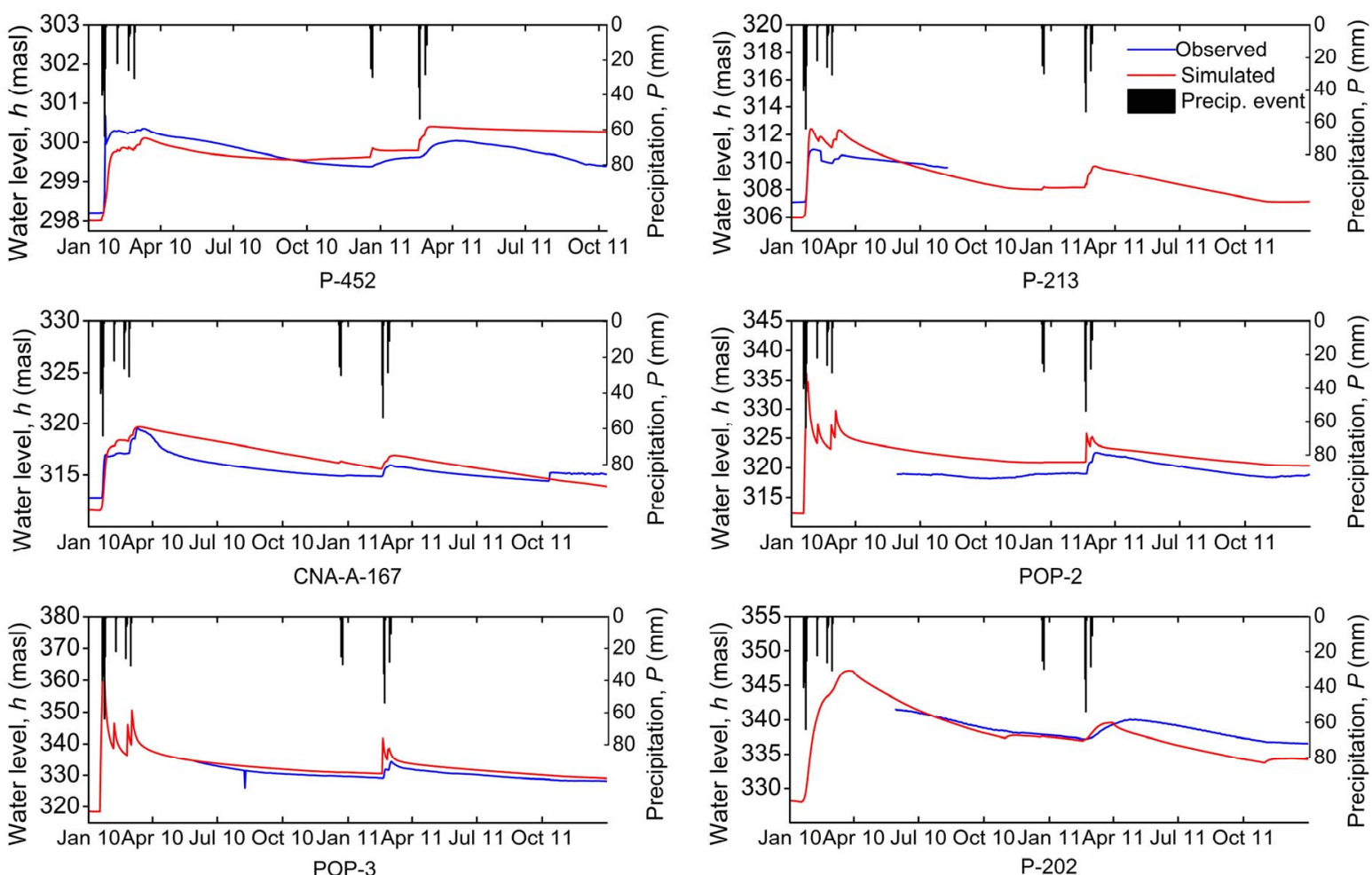

Figure 6. Observed and simulated water table response and its associated extraordinary precipitation event in the wells $P-452$, P-213, CNA-A-167, POP-2, POP-3 and P-202, located in the Guadalupe river area. 

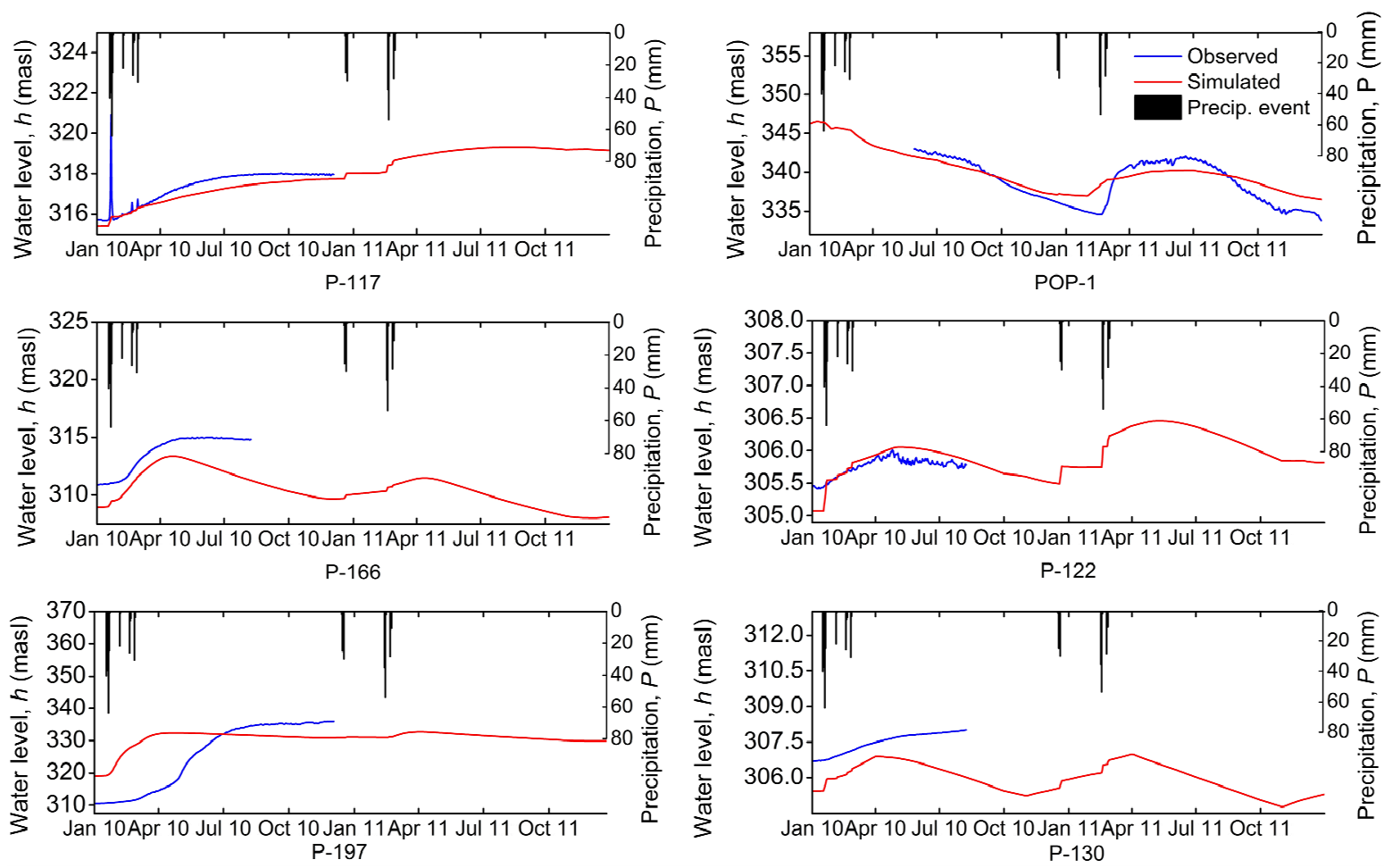

Figure 7. Observed and simulated water table response and its associated extraordinary precipitation event in the wells $P-117$, POP-1, P-166, P-122, P-197 and P-130.

significant peak in the measured and simulated water table is directly related to the rainfall event of days 18 , 19, 20, 21 and 22 of January 2010; a second relevant increment related to the rainfall events of February 18 and 19 of 2011 can be observed. A third water table increment occurring on October 2011 was located in the water table record of well CNA-A-167 (Figure 6); this peak could not be associated with any extraordinary precipitation event, so it is inferred that this increase in the record could be the result of mismanagement of the logger in the process of extraction, data acquisition and reinstallation of it.

The greatest discrepancy between the observed and simulated data was observed in the P-197 well (Figure 7), this may be due the depth of the confining bedrock, which is deeper in this zone than other areas in the valley allowing a complex material configurations leading to different hydraulic conductivities. Such issue can possibly be solved by running a simulation on a three dimensional model using several vertical layers for a better representation of the real study area.

\section{Conclusions}

According to the analyzed data and the model results, we can establish two types of responses: Slow response, which is given by the volume from vertical recharge that occurs in the aquifer area and the horizontal recharge thru the different recharge zones; and the quick response, dominated by the volume, product of extraordinary precipitation events, that enters to the valley as superficial flow and then infiltrates downstream.

In all the data provided by the monitoring wells away from the Guadalupe river stream area, the water table level response is mainly due to vertical and horizontal recharges, the sudden water level increments (both, observed and simulated) due to extraordinary precipitations were not as relevant in these wells as in those located in the river stream area.

In all the studied information the maximum lag between the extraordinary precipitation events and the water table level response in the aquifer was of 9 days, this implies that the effect of flash flood dominates the observed and simulated anomalous peaks and forms the main recharge mechanism of the system. On the other hand such lag seems to be determined by the intensity of the extraordinary precipitation event.

\section{REFERENCES}

[1] R. Vázquez, C. Traslosheros, M. Vega, R. Vega and J. M. Espinoza, "Geohydrologic Evaluation in Northwest Baja California," Technical Inform, Earth Sciences Division, Center for Scientific Research and Higher Education at Ensenada, Ensenada, 1991, 49p.

[2] J. R. Campos, "Groundwater Flow Simulation in the Aq- 
uifer of Guadalupe Valley, Baja California," Ph.D. Dissertation, Center for Cientific Research and Higher Education at Ensenada, Ensenada, 2008.

[3] E. García, "Modifications to Köpen Climatic Clasification System," Geography Institute, National Autonomous University of Mexico, Mexico City, 1981, 244p.

[4] J. J. Escarrega, G. E. Terán and C. Siqueiros, "Geological-Mining Chart Tijuana I11-11 Baja California," Geologic Chart, Mexican Geological Service, Hidalgo, 2003.

[5] J. R. Campos and T. Kretzschmar, "Numerical Understanding of Regional Scale Water Table Behavior in the Guadalupe Valley Aquifer, Baja California, Mexico," Hydrology and Earth System Sciences Discussions, Vol. 3, No. 3, 2006, pp. 707-730.

http://www.hydrol-earth-syst-sci-discuss.net/3/707/2006/ hessd-3-707-2006.pdf

[6] L. Nájera, “A Geophysical Study of El porvenir Sedimentary Basin, Ensenada Municipality, Baja California, Mexico," M.S. Dissertation, Center for Scientific Research and Higher Education at Ensenada, Ensenada, 2006.

[7] R. Vazquez, J. M. Romo and T. Kretzschmar, “Technical
Studies for the Integrated Management of Water in the Guadalupe Valley and Elaboration of COTAS Strengthening Scheme," Technical Inform, Earth Sciences Division, Center for Scientific Research and Higher Education at Ensenada, Ensenada, 2007, 53p.

[8] CNA, "Actualization of Groundwater Annual Average Availability, Aquifer (0207) Guadalupe, State of Baja California," Technical Inform, Technical Department, Groundwater Management, Aquifer Order and Evaluation Submanagement, 2009, 18p.

[9] USGS, "Shuttle Radar Topography Mission Data," 2010. http://srtm.usgs.gov/index.php

[10] N. Kresic, "Quantitative Solutions in Hydrogeology and Groundwater Modeling," CRC Press, Lewis Publishers, New York, 1997, 461p.

[11] V. M. Ponce, R. P. Pandey and S. Kumar, "Groundwater Recharge by Channel Infiltration in El Barbon Basin, Baja California, Mexico," Journal of Hydrology, Vol. 214, No. 1-4, 1999, pp. 1-7. doi:10.1016/S0022-1694(98)00220-0 